Pesq. Vet. Bras. 29(1):76-82, janeiro 2009

\title{
Development and evaluation of a recombinant DNA vaccine candidate expressing porcine circovirus 2 structural protein ${ }^{1}$
}

\begin{abstract}
Abelardo Silva Júnior ${ }^{2,3}$, Luiza A. Castro², Orlando Chiarelli Neto², Fernanda M.F. Silva ${ }^{2}$, Pedro M.P. Vidigal ${ }^{2}$, Mauro P. Moraes ${ }^{4}$ and Márcia R. Almeida ${ }^{2 *}$

ABSTRACT.- Silva Júnior A., Castro L.A., Chiarelli Neto O., Silva F.M.F., Vidigal P.M.P., Moraes M.P. \& Almeida M.R. 2009. Development and evaluation of a recombinant DNA vaccine candidate expressing porcine circovirus 2 structural protein. Pesquisa Veterinária Brasileira 29(1):76-82. Laboratório de Infectologia Molecular Animal, Instituto de Biotecnologia Aplicada à Agropecuária, Universidade Federal de Viçosa, Av. PH Rolfs s/n, Campus Universitário, Viçosa, MG 36570-000, Brazil. E-mail: marcia@ufv.br

Porcine circovirus 2 (PCV2) is generally associated with the porcine circovirosis syndrome, which is considered an important disease of swine and has potentially serious economic impact on the swine industry worldwide. This article describes the construction of a recombinant plasmid expressing the PCV2 structural protein and the evaluation of cellular and humoral immune responses produced by this recombinant vaccine in BALB/c mice. The vaccine candidate was obtained and analyzed in vivo, in an effort to determine the ability to induce a specific immune response in mice. DNA was extracted from a Brazilian PCV2 isolate and the gene coding for Cap protein was amplified by PCR and inserted into an expression plasmid. Groups of BALB/c mice were inoculated intra-muscularly and intradermally in a 15-day interval, with $100 \mu \mathrm{g}$ and $50 \mu \mathrm{g}$ of the vaccine construct, respectively. Another group was inoculated intramuscularly with $100 \mu \mathrm{g}$ of empty plasmid, corresponding to the control group. Seroconversion and cellular response in BALB/c mice were compared and used for vaccine evaluation. Seroconversion was analyzed by ELISA. After a series of 3 immunizations the spleen cells of the immunized animals were used to perform lymphocyte proliferation assays. Seroconversion to PCV2 was detected by ELISA in the animals inoculated with the vaccine construct when compared with control groups. Lymphocyte proliferation assays showed a stronger cell proliferation in the inoculated animals compared with the control group. Thus, the vaccine candidate construct demonstrated to be able to induce both humoral and cellular responses in inoculated mice.
\end{abstract}

INDEX TERMS: PCV2, DNA vaccine, porcine circovirosis.

RESUMO.- [Desenvolvimento e avaliação de um candidato à vacina de DNA recombinante expressando a proteína estrutural do circovírus suíno 2.] O circovírus suíno 2 (PCV2) é geralmente associado à síndrome da

\footnotetext{
${ }^{1}$ Received on April 1, 2008.

Accepted for publication on August 28, 2008;

2 Laboratório de Infectologia Molecular Animal, Instituto de Biotecnologia Aplicada à Agropecuária (Bioagro), Universidade Federal de Viçosa (UFV), Av. PH Rolfs s/n, Campus Universitário, Viçosa, MG 36570-000, Brazil. *Corresponding author: marcia@ufv.br

${ }^{3}$ Laboratório de Virologia Animal, Departamento de Veterinária, UFV, Viçosa, MG.

${ }^{4}$ Plum Island Animal Disease Center. PO Box 848, Greenport, NY 11944-0848, USA.
}

circovirose suína, que é considerada uma importante doença de suínos e possui um sério impacto econômico na suinocultura mundial. Este trabalho descreve a construção de um plasmídeo recombinante que expressa a proteína estrutural do PCV2 e a avaliação das respostas imune humoral e celular por meio de vacinação em camundongos BALB/c. O candidato vacinal foi submetido a análises in vivo, determinando a capacidade de induzir resposta imune específica em camundongos. O DNA de um isolado brasileiro de PCV2 foi extraído e o gene que codifica para a proteína do capsídeo foi amplificado por PCR e inserido num plasmídeo de expressão. Grupos de camundongos $\mathrm{BALB} / \mathrm{c}$ foram inoculados por via intramus-

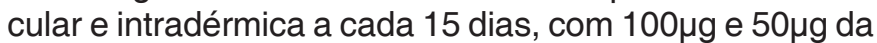


construção vacinal, respectivamente. Outro grupo foi inoculado com $100 \mu \mathrm{g}$ do plasmídeo original, correspondente ao grupo controle. A soroconversão e a resposta celular dos grupos de camundongos BALB/c vacinados foram comparados como parâmetros de avaliação vacinal. A soroconversão foi avaliada por um teste de ELISA. Após 3 imunizações, as células esplênicas dos animais imunizados foram utilizadas nos ensaios de linfoproliferação. A soroconversão para o PCV2 foi detectada por ELISA nos animais inoculados com a construção vacinal quando comparados com o grupo controle. Nos ensaios de linfoproliferação foi observada uma grande proliferação celular nos animais inoculados comparados ao grupo controle. Portanto, o candidato vacinal demonstrou ser capaz de induzir tanto uma resposta humoral e celular nos camundongos inoculados.

TERMOS DE INDEXAÇÃO: PCV2, vacina de DNA, circovirose suína.

\section{INTRODUCTION}

Porcine circovirus (PCV), a member of the family Circoviridae (Lukert et al. 1995) along with other animal circoviruses, is one of the smallest viruses replicating autonomously in mammalian cells. PCV is an icosahedral nonenveloped virus of $17 \mathrm{~nm}$ in diameter with a singlestranded circular DNA genome of about $1.76 \mathrm{~kb}$ (Tischer et al. 1982, Hamel et al. 1998). There are currently two types of PCV recognized, PCV1 and PCV2. PCV1 was originally identified in the porcine kidney (PK15) cell line (ATCC-CCL31) (Tischer et al. 1982) and it is considered a nonpathogenic virus, whereas PCV2 is associated with postweaning multisystemic wasting syndrome (PMWS) (Harding \& Clark 1997, Allan et al. 1998, Ellis et al. 1998).

PCV2 is frequently associated with PMWS, as well as other clinical conditions such as porcine dermatitis and nephropathy syndrome (PDNS) (Thibault et al. 1998), lateterm abortions (West et al. 1999), reproductive failure in sows (Park et al. 2005), proliferative and necrotizing pneumonia (PNP) and congenital tremors (Allan et al. 1998, Kim et al. 2002). PMWS primarily affects pigs between 5 and 18 weeks of age. Clinical signs include progressive dyspnea, weight loss, jaundice, emaciation, and respiratory and digestive disorders (Harding \& Clark 1997, Lecann et al. 1997, Nayar et al. 1997). PCV2 associated ailments are considered important swine diseases and have potentially serious economic impact on the swine industry worldwide (Allan et al. 1999, Rodriguez-Arrioja et al. 2002, Hasslung et al. 2003). PCV2 viral particles are very stable and are able to persist in the environment of infected herds, making virus eradication very difficult (Cho et al. 2006). For disease control, alternative strategies should therefore be investigated and immune prophylaxis could be an adequate strategy. The high conservation degree in structural genes among different PCV2 isolates should make a monotypic vaccine approach possible.

Some vaccines for PCV2 are currently under testing while other are being marketed in Europe and North America (Castro et al. 2007), and recently in Brazil. The available vaccine formulations consist of inactivated virus (Castro et al. 2007), Cap protein expressed in baculovirus system (Kolb 2007) and chimeric virus containing the portion of the immunogenic cap gene of PCV2 inserted into the PCV1 genome (Fenaux et al. 2004).

The PCV2 genome contains three major open reading frames; ORF1 encoding Rep and Rep' proteins involved in viral replication (Mankertz et al. 1998); ORF2 encoding the capsid protein (Cap) (Nahagitgul et al. 2000), major structural and immunogenic protein of PCV2; and ORF3 encoding a protein involved in virus induced apoptosis (Liu et al. 2005). Cap protein has been reported to induce protective responses in pigs injected with baculovirusexpressed product or prepared ORF2 DNA (Blanchard et al. 2003, Kamstrup et al. 2004). Neutralizing monoclonal antibodies and neutralizing swine sera have been shown to react with Cap protein (Mcneilly et al. 1996, Pogranichnyy et al. 2000, Lekcharoensuk et al. 2004). PCV2 ORF1 and ORF2 subunit vaccines have been developed and were shown to provide significant protection against PCV2 infection (Blanchard et al. 2003).

Studies on humoral immune response to PCV2 have demonstrated that IgG and IgM antibody profiles in subclinically infected pigs are fairly standard for a virus, with the exception that both immunoglobulins appear to be elicited relatively late post-viral infection (Allan 2007).

Given that growth and purification of PCV2 to a satisfactory antigen level is laborious, alternative approaches for vaccination should be chosen, such as genetic immunization. DNA vaccination technology has been adapted to pigs and successful vaccination against different pathogens has proven the applicability of this technology (Gerdts et al. 1997, Benvenisti et al. 2001). This report describes the construction of a recombinant plasmid expressing PCV2 structural protein and the evaluation of cellular and humoral immune responses towards the virus in immunized BALB/c mice.

\section{MATERIALS AND METHODS}

Cells and viruses. A Brazilian PCV2 isolate previously characterized (GenBank accession number DQ364650) was propagated in a PCV2-negative swine kidney cell line SK-6. Cells were grown and maintained in Minimum Essential Medium (MEM, Cultilab, Brazil), supplemented with $10 \%$ (v/v) heatinactivated fetal calf serum (FCS), $100 \mu \mathrm{g} / \mathrm{ml}$ streptomycin and $100 \mathrm{IU} / \mathrm{ml}$ penicillin. PCV2 was inoculated when cells were semiconfluent; inoculated cells were incubated for $2 \mathrm{~h}$ at $37^{\circ} \mathrm{C}, 5 \%$ $\mathrm{CO}_{2}$. MEM supplemented with antibiotics and $10 \%$ FCS (Cultilab, Brazil) was added to the cultures after adsorption and incubated for $48 \mathrm{~h}$. After incubation, cells were treated with D-glucosamine $300 \mathrm{mmoles} / \mathrm{l}$ (Sigma, USA) for $45 \mathrm{~min}$ and re-incubated for 48 h. When cells reached confluence, the supernatant was removed and cells were washed three times with phosphate-buffered saline (PBS). The virus was harvested by freezing and thawing the infected cells three times in a small volume of PBS. The resulting cell debris was clarified by centrifugation, and the viral 
genomic DNA was extracted as described by Sambrook et al. (1989) with slight modifications.

Amplification of PCV2 structural gene. DNA from PCV2 served as template for ORF2 amplification. Based on the genomic sequence of PCV2 (GenBank Accession No. DQ364650), the following oligonucleotides were used: the upstream oligonucleotide 5'-GGCTAGCCGATGACGTATC CAAG-3' containing the Nhel site and the downstream oligonucleotide 5'-GACGCGTCGTTAGGGTTTAAGTG-3' containing the Mlul site. PCR was performed in a $25 \mu l$ reaction mixture containing $1.0 \mathrm{U}$ of Taq DNA polymerase (Invitrogen, USA), $200 \mathrm{mM}$ of each dNTP, $0.5 \mathrm{mM}$ of each oligonucleotide, 10X PCR buffer [Tris- $\mathrm{HCl} 20 \mathrm{mM}(\mathrm{pH} 8.4), \mathrm{KCl} 50 \mathrm{mM}$ ] and $2 \mathrm{mM}$ $\mathrm{MgCl}_{2}$. The reaction was performed in a PTC-100 thermal controller (Watertown, MJ Research Inc.,USA) programed as follows: denaturation at $94^{\circ} \mathrm{C}$ for $5 \mathrm{~min}, 35$ cycles of denaturation at $94^{\circ} \mathrm{C}$ for $60 \mathrm{~s}$, annealing at $60^{\circ} \mathrm{C}$ for $60 \mathrm{~s}$ and extension at $72^{\circ} \mathrm{C}$ for $1 \mathrm{~min}$, with a final extension step at $72^{\circ} \mathrm{C}$ for $10 \mathrm{~min}$. A DNA sequence of the expected size was obtained, confirmed by gel electrophoresis, and the PCR product was then purified using GFX ${ }^{\mathrm{TM}}$ PCR DNA and Gel Band Purification Kit (Amersham Biosciences, USA) as specified by the manufacturer.

Construction of plasmids expressing PCV2 Cap protein. The purified PCR product and the mammalian expression vector pCIneo (Promega, USA) were digested with Mlul and Nhel (Promega, USA) at $37^{\circ} \mathrm{C}$ for $2 \mathrm{~h}$. The digested plasmid and PCR product were ligated using $1 \mathrm{U}$ of T4 DNA ligase at $14^{\circ} \mathrm{C}$ for 14 h (Promega, USA). Escherichia coli DH5 $\alpha$ competent cells were transformed with the resulting recombinant plasmid, named pCap. Positive clones were screened by PCR and restriction enzyme digestion. Insert identity was verified by sequencing with external oligonucleotides in an automated Sequence Detector System (ABI Prism 377 Genetic Analyzer; Applied Biosystems, Foster City, CA) using a commercially available kit (ABI PRISM BigDye III Terminator Cycle Sequencing Ready Reaction $®$, Applied Biosystems) according to the manufacturer's protocol.

Expression of Cap protein by recombinant plasmid. The expression of PCV2 ORF2 by the recombinant plasmid was analyzed by transfecting PCV2-free SK6 cells using a cationic lipid based delivery. Briefly, 20 $\mu \mathrm{g}$ of plasmid DNA were mixed with Lipofectamine 2000 (Invitrogen, USA) at a lipid:DNA ratio of $2: 1 \mathrm{in} 1 \mathrm{ml}$ of Opti-MEM (Sigma, USA) and incubated for 45 min at room temperature. The mixture was added to cells grown to about $90 \%$ of confluence in 6-well plates (Corning, USA) and incubated at $37^{\circ} \mathrm{C}$ in a $5 \% \mathrm{CO}_{2}$ incubator for $48 \mathrm{~h}$. After incubation, the cultures were processed for detection of the Cap protein.

Expression of PCV2 ORF2 in transfected cells was tested by indirect immunofluorescence assay (IFA) using a swine polyclonal antibody against PCV2 as primary antibody (VMRD Inc., USA). Briefly, transfected cells were washed with PBS and fixed with a cold acetone solution for $15 \mathrm{~min}$. Fixed cells were then washed two times with PBS. PCV2-positive (VMRD Inc., USA) and negative pig sera were diluted at 1/50 in PBS and incubated with cells for $1 \mathrm{~h}$ at $37^{\circ} \mathrm{C}$. Cells were washed with PBS for $15 \mathrm{~min}$ and then incubated with rabbit anti-pig immunoglobulin G-FITC (fluorescein isothiocyanate conjugate (Sigma, USA) diluted $1 / 100$ in PBS during $60 \mathrm{~min}$ at $37^{\circ} \mathrm{C}$ in a humid chamber. After incubation period, the slide was washed with PBS three times and dried at room temperature. Cells transfected with the original plasmid (without the insert) and PCV2-infected SK6 cells were used as controls. Cells were observed and photographed with an epifluorescence microscope (Nikon eclipse E600, Japan).

DNA vaccination protocol. Plasmid DNA was extracted using EndoFree® Plasmid Purification Giga Kit (Qiagen, Germany) according to manufacturer's recommendations. Fifteen 4-week-old female Balb/c mice were randomly divided into three groups containing five animals each. Group 1 animals were injected intramuscularly with $100 \mu \mathrm{g}$ of the plasmid vaccinal construct. Group 2 mice were inoculated intradermally with $50 \mu \mathrm{g}$ of the construct. Mice of Group 3 received 100 $\mu \mathrm{g}$ of empty plasmid intramuscularly as a control. Mice were primed on day 0 and boosted on days 15 and 30 with recombinant DNA in PBS solution. In parallel, five BALB/c mice were immunized three times into the quadriceps muscle with $50 \mu \mathrm{g}$ of purified inactivated PCV2 to produce a reference serum for use in serological tests. Blood samples were obtained prior to boosting and also 15 days after the last inoculation and processed for separation of the serum. Sera from these mice were stored at $-70^{\circ} \mathrm{C}$ until use. After immunizations, the spleen of the immunized animals was isolated and cells were cultivated in a concentration of $2 \times 10^{5}$ cells/well to perform lymphocyte proliferation assays.

Detection of antibodies to PCV2 structural protein by indirect ELISA. PCV2 specific antibody was detected by a solidphase enzyme-linked immunosorbent assay (ELISA) using 96well ELISA plates coated with PCV2 purified particles. Virus was purified under discontinuous $\mathrm{CsCl}$ gradient. The quality and concentration of the purified viral particles were evaluated by electronic microscopy and absorbance spectra reading. Briefly, 96-well microtiter plates (Corning, USA) were coated overnight at $4^{\circ} \mathrm{C}$ with $1.25 \mu \mathrm{g} / \mathrm{ml}$ of purified viral particles in carbonate coating buffer for $16 \mathrm{~h}$. After incubation period plates were washed with PBST (PBS pH 7.4 and Tween-20 0.05\%) and then blocked for $1 \mathrm{~h}$ at room temperature with $2 \%$ sodium casein in wash buffer. One hundred microliters of each serum sample diluted 1:20 in PBST were added to each well. The serum samples were tested in duplicate and positive and negative control sera were included in each plate. Positive control consisted on hyperimmune mouse sera inoculated with the purified virus and negative controls consisted on mice inoculated with empty plasmid. The sera were incubated at room temperature for $2 \mathrm{~h}$ and then washed five times with PBS buffer containing $0.1 \%$ Tween-20. The plates were further incubated with horseradish peroxidase-conjugated rabbit anti-mouse IgG (Sigma, USA) diluted 1:8.000 at room temperature for $2 \mathrm{~h}$. Plates were washed again and incubated with $0.1 \mathrm{M}$ sodium citrate buffer ( $\mathrm{pH} 5.0$ ) containing $2.2 \mathrm{mM} \mathrm{O}$-phenylenediamine and $0.045 \% \mathrm{H}_{2} \mathrm{O}_{2}$ at room temperature during $15 \mathrm{~min}$. The reaction was terminated with $2 \mathrm{M} \mathrm{H}_{2} \mathrm{SO}_{4}$ and plates were read at $492 \mathrm{~nm}$ in Microplate Reader 3550 (Bio-Rad, USA). The cutoff O.D. value for determining serum positivity was calculated as the mean optical density (O.D.) of the negative control sera plus 2 standard deviation (S.D.).

PCV2 specific lymphocyte proliferation response assay. PCV2 specific lymph proliferative responses mounted by DNAvaccinated mice were determined by MTT (3- $(4,5-$ dimethylthiazol-2-yl)-2,5-diphenyltetrazolium bromide) colorimetric assay adapted from Abe \& Matsuki, 2000. Spleens were prepared from mice of Group 1, 2 and 3, fifteen days after the last inoculation. Cell suspensions were treated with Tris-buffered ammonium chloride [Tris- $\left.\mathrm{HCl} 0.17 \mathrm{M}: \mathrm{NH}_{2} \mathrm{Cl} 0.16 \mathrm{M}(1: 9)\right](\mathrm{pH}$ 7.4 ) to eliminate the red blood cells, and resuspended in RPMI 
1640 supplemented with 5\% FBS, HEPES buffer, L-glutamine, penicillin and streptomycin. Cell viability was assessed by trypan blue dye exclusion and counted in a Neubauer chamber. Splenocytes were cultured in triplicate in 96-well flat-bottom microtiter plates (Corning, USA) $\left(2 \times 10^{5}\right.$ cells $/ 100 \mu$ l per well) in the presence of inactivated PCV2, control RPMI medium, and Concanavalin A $(4 \mu \mathrm{g} / \mathrm{ml})$. The proliferation response was measured by MTT dye assay. After incubation for $72 \mathrm{~h}, 60 \mu \mathrm{g}$ of MTT was added to each well and the plates were re-incubated for additional $4 \mathrm{~h}$. At the end of incubation, MTT was removed and the cells were treated with $100 \mu \mathrm{l}$ of $\mathrm{HCl}$-isopropanol $(0.04 \mathrm{~N}$ $\mathrm{HCl})$ for crystal solubilization. The plates were read at $492 \mathrm{~nm}$ in Microplate Reader 3550 (Bio-Rad, USA).

Statistical analysis. Summary statistics were calculated for all groups to assess the overall quality of the data. ELISA assay data were examined by analysis of variance (ANOVA) $(P<0.05)$. Differences between the vaccinated groups in the lymphocyte proliferation assay were compared by t-tests $(P<0.05)$.

\section{RESULTS}

Construction of the recombinant plasmid containing PCV2 ORF2. After cloning the 720bp obtained by PCR amplification of viral sequences, the presence of Cap protein gene in the pCap plasmid was confirmed by PCR and restriction analysis. Plasmidial DNA containing the viral capsid-encoding region was subjected to cleavage reaction with the restriction enzymes Nhel/Mlul that originated fragments of $5470 \mathrm{bp}$ e $710 \mathrm{bp}$. The obtained DNA fragments showed to be in the expected size (Fig.1A). The nucleotide sequence of PCV2 ORF2 in the recombinant plasmid pCap was identical to the original sequence at GenBank (no.DQ364650) and was maintained in frame (Fig.1B).

Expression of PCV2 ORF2 by the recombinant plasmid in SK6 cells. The pCap plasmid was used for transfection of SK6 cells. SK6 cells transfected with 20 $\mu \mathrm{g}$ of pCap were collected after $48 \mathrm{~h}$ and Cap protein was detected by IFA. The results showed staining of transfected SK6 cells, indicating that PCV2 capsid protein was expressed. Control cells showed no staining with the PCV2 antibody (Fig.2).

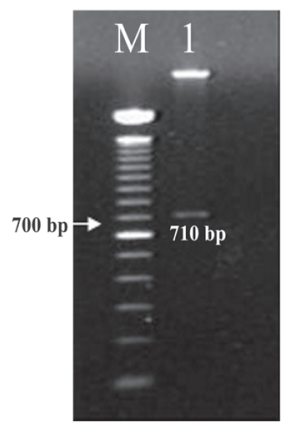

A

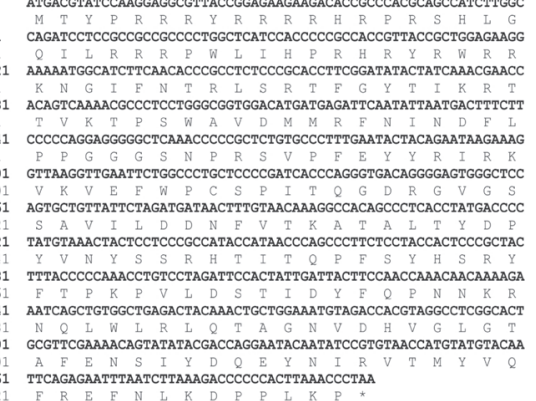

B
Fig.1. (A) pCap digested with Mlul and Nhel enzymes. M: Ladder $100 \mathrm{bp}, 700 \mathrm{bp}$ is indicated by arrow. 1: ORF2 DNA recombinant fragment of $710 \mathrm{bp}$ is indicated. (B) ORF2 nucleotides sequence of the recombinant plasmid (pCap).
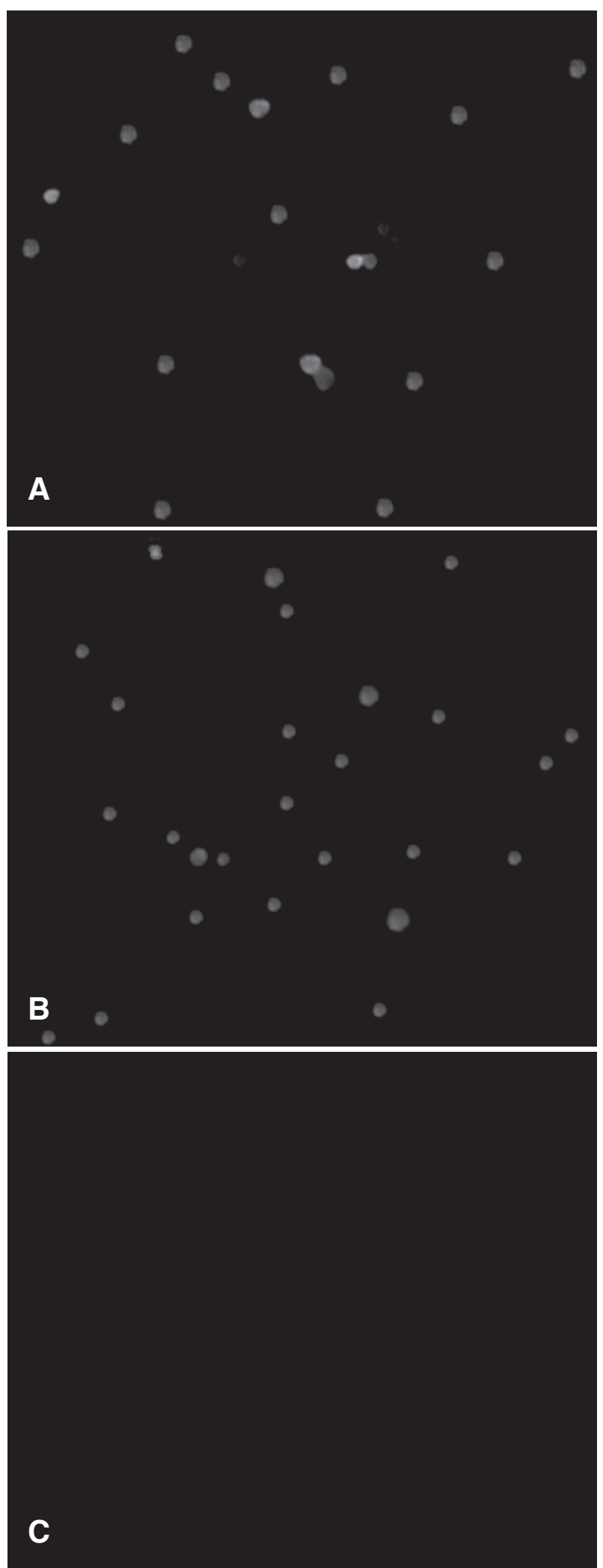

Fig.2. Detection of porcine circovirus 2 (PCV2) capsid protein in vitro by immunofluorescence. (A) SK6 cells infected with PCV2 (positive control). (B) PCV free SK6 cells transfected with pCap. (C) Mock transfected SK6 cells (negative control). Magnification 100x. 


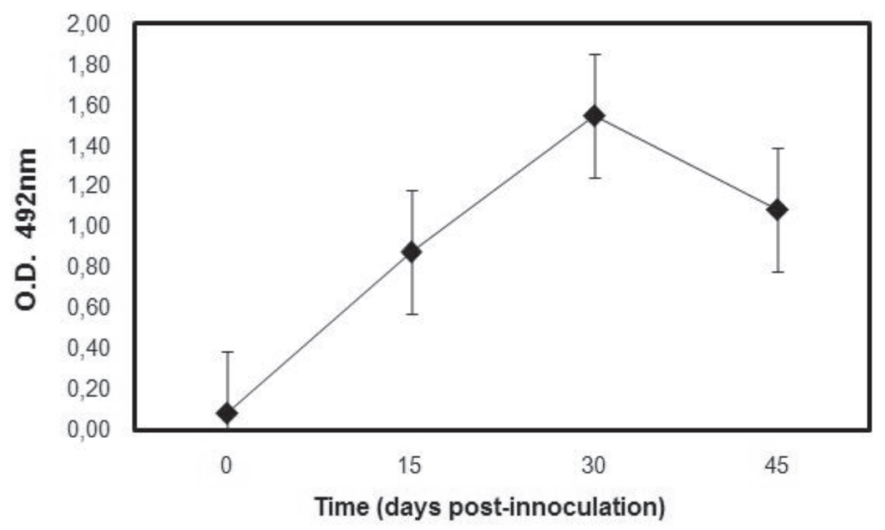

Fig.3. ELISA standardization. PCV2-specific antibodies elicited in animals inoculated with inactivated purified virus.

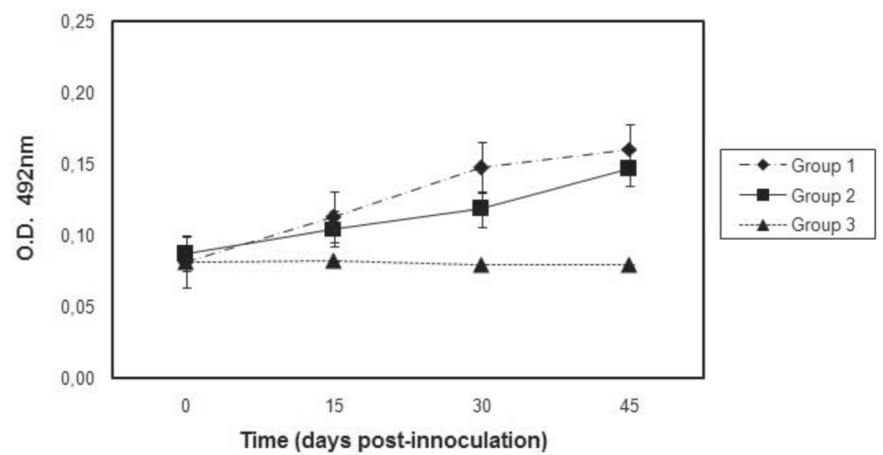

Fig.4. PCV2-specific antibodies elicited in the DNA-vaccine groups represented by animals intramuscularly (Group 1) and intradermally (Group 2) inoculated with pCap, and animals inoculated with empty plasmid (Group 3). ODs are indicated for mice antisera collected before inoculation (0) and at two week intervals (15, 30 and 45). The mean standard deviation for five mice in each group is shown.

PCV2 specific antibody response induced by pCap in immunized mice. Serum samples collected from all control and inoculated animals at $0,15,30$ and 45 days were assayed for anti-PCV2 Cap protein antibody by ELISA to evaluate anti-PCV2 antibody production in response to immunization with the recombinant plasmid. Prior to inoculation at $0 \mathrm{dpi}$, animals from all groups were tested for PCV2 by ELISA. The animals inoculated with purified virus showed titers of anti-PCV2 antibodies in ELISA standardization (Fig.3). Negative-control animals (Group 3) were negative to PCV2 throughout the study. Antibody in the sera of mice injected with the recombinant plasmid could only be detected after the second inoculation. Following a boost at day 15 , antibodies gradually increased in mice vaccinated with pCap. No antibody against PCV2 was detected over the 45 days in the negative control group (Fig.4). Analysis of variance $(P<0.05)$ showed that mice of Group 1 and 2 showed higher antibodies titers than mice of Group 3.

PCV2 specific lymphocyte proliferation in DNA vaccinated mice. To evaluate if the plasmid DNA immunization would induce PCV2-specific lymph-
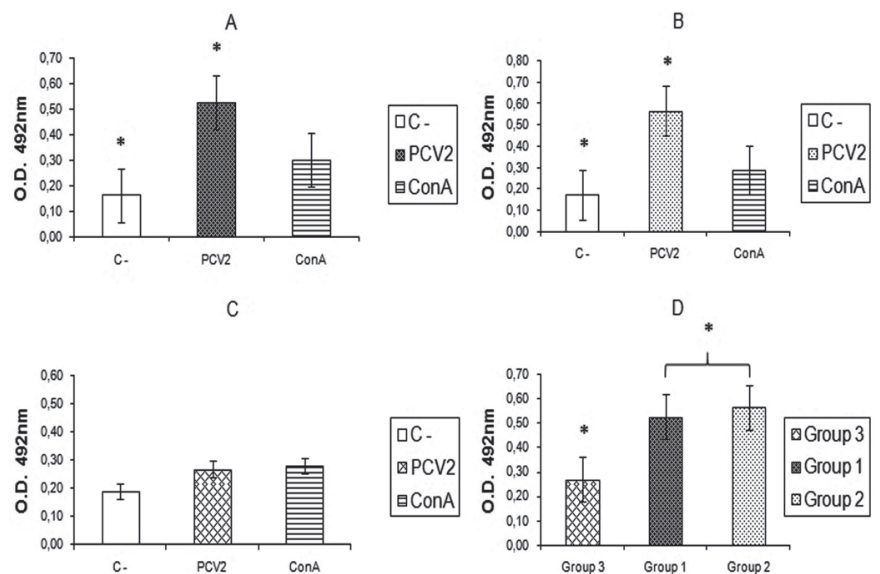

Fig.5. Lymphoproliferation assays of spleen cells from animals inoculated with pCap and empty plasmid in the presence of different stimulus. C-: Negative control (spleen cells treated with RPMI medium); PCV2 (cells treated with the purified virus); ConA (cells treated with Concanavalin A). (A) Spleen cells from mice intramuscularly inoculated with pCap (Group 1). (B) Spleen cells from mice intradermally inoculated with pCap (Group 2). (C) Spleen cells from mice intramuscularly inoculated with empty plasmid (Group 3). (D) Comparison of groups 1, 2 and 3 for proliferation in the presence of PCV2. * Significant difference between groups $(\mathrm{P}<0.05)$.

proliferative response, BALB/c mice were inoculated with recombinant plasmids three times. Fifteen days after the last inoculation, mice were sacrificed and splenocytes were prepared to examine the proliferation in response to specific antigen stimulation. Using the tetrazolium salt reduction (MTT), which is an indicator of cell growth, the PCV2 recognition by lymphoid cells from $\mathrm{pCap}$ vaccinated mice was evaluated in vitro by lymphocyte proliferation assays. Spleen lymphocytes derived from recombinant vaccine-inoculated animals demonstrated a proliferative response to specific stimuli, as shown on Fig.4. Splenocytes from animals inoculated intradermally and intramuscularly presented a proliferative response when PCV2 was introduced. This response was statistically different $(P<0.05)$ from the animals inoculated only with RPMI medium. PCV2 specific proliferation response was significantly higher in mice from Group 1 and 2 than in Group 3 mice $(P<0.05)$.

\section{DISCUSSION}

Commercially available vaccines are based on attenuated microorganisms, live inactivated microorganisms, microorganisms' extracts or recombinant proteins. There is, however, a tendency towards the development of new vaccines, as subunit and DNA vaccines (Van Oirschot 2001). Because of difficulties in obtaining high PCV2 titers in vitro, potential recombinant vaccines would be particularly useful in this viral system. Immunization based on DNA vaccines has more advantages than the conventional vaccination methods as it eliminates the need to perform conventional antigen preparation, which is rather laborious. 
It enables the use of a more pure immunogen, since plasmidial preparations could be easily purified, besides being capable of inducing immunity even in the presence of maternal antibodies (Hassett et al. 1997, Fischer et al. 2003). Differently from inactivated or subunit vaccines, DNA vaccines may result in an antigenic presentation via Class I and Class II MHC molecules, which mimics the resulting response to natural infection, inducing $\mathrm{CD}^{+}$and $\mathrm{CD} 8^{+} \mathrm{T}$ lymphocytes and antibody production. This vaccine strategy can thus induce potent cellular and humoral responses (Ulmer et al. 1996). The vector used in DNA vaccination could have immunoestimulant properties, such as nonmetilated nucleotides (CpG), acting as adjuvant, enhancing the magnitude of the immune response and influencing cell pattern response (Krieg 2002).

Monoclonal antibodies (Mabs) with neutralizing activity have been reported to react with Cap protein (Kim et al. 2002, Zhou et al. 2005). Likewise, sera from naturally infected swine also recognized this protein (Pogranichnyy et al. 2000). Blanchard et al. (2003) demonstrated that ORF2 constructions inoculated in swine induce a higher protection level than ORF1 constructions. Lekcharoensuk et al. (2004) produced truncated versions of Cap protein, which were proven to have three regions constituting conformational epitopes that are recognized by monoclonal antibodies.

Aiming to further explore PCV2 capsid protein applicability as a vaccine candidate, the gene encoding viral capsid was cloned in the mammalian expression pCIneo. This plasmid contains a potent enhancer derived from CMV, a quimeric intron, and also non-methylated nucleotide sequences connected by phosphodiester bonds (CpG) that are important immune response stimulators (Krieg 2002). This vaccine candidate was analyzed in relation to the in vitro expression of Cap protein by IFA, and in vivo expression by antibody induction and cell proliferation in plasmid-immunized mice.

The production of anti-PCV2 hyperimmune serum in mice was necessary in order to evaluate the antibody production by vaccinated animals. However, the animals inoculated with purified PCV2 should not constitute a control group to assess the candidate vaccine, given that the imunization with purified inactivated virus is direct antigen application (Lambert et al. 2005), whereas the DNA vaccination assay is an in vivo transfection assay (Babiuk et al. 2003). Sera of these animals were produced only for ELISA standardization. The types of immune responses are different for the two assays and, therefore, the immune response by these groups should not be compared.

During in vivo assays, mice vaccinated intradermally and intramuscularly with recombinant plasmid seroconverted to anti-PCV2 within 2 weeks after vaccination. Control animals inoculated with nonrecombinant plasmid remained seronegative. The ELISA assay showed that the animals inoculated with the recombinant plasmid produced a humoral immune response against Cap protein.
Cellular immunity was evaluated by lymphoproliferation assays, and a detectable proliferation response was observed with the spleen lymphocytes derived from pCapinoculated animals. Spleen lymphocytes from intradermally and intramuscularly inoculated mice proliferated when treated with virus. This response was statistically different $(P<0.05)$ from mice treated only with RPMI media. There were also clear differences in the magnitude of the proliferation response $(\mathrm{P}<0.05)$ in vaccinated groups when compared with animals inoculated with empty plasmid, showing an immunoreactive effect in the vaccinated animals. Group 1 and 2 were not statistically different $(\mathrm{P}<0.05)$.

The lymphoproliferation assay showed that animals intradermally and intramuscularly inoculated with the vaccine construct had a similar proliferation index. Further studies are required to establish the most adequate route of inoculation, since the same plasmid may be capable of inducing different types of immune response depending on this route (Sharma \& Khuller 2001). Spleen cells treated with ConA (positive control) produced lymphoproliferation weaker than that of PCV2 treated cells.

The vaccine candidate construct expressed the ORF2 gene (Cap protein) and its administration to mice induced cellular and humoral responses. Nonetheless, a vaccination and experimental challenge protocol are still needed to improve the vaccine performance.

Acknowledgements.- To FAPEMIG for financial support of the project. We would also like to thank Prof. Joaquín Hernán Patarroyo Salcedo for the assistance and availability of the Laboratory of Biology and Control of Hematozoaire and Vectors, and Prof. Sérgio Oliveira de Paula for his useful comments and meaningful discussion. Abelardo Silva Júnior has a fellowship from CNPq (Doctorate scholarship).

\section{REFERENCES}

Abe K. \& Matsuki N. 2000. Measurement of cellular 3-(4,5dimethylthiazol-2-yl)-2,5-diphenyltetrazolium bromide (MTT) reduction activity and lactate dehydrogenase release using MTT. Neurosci. Res. 38:325-329.

Allan G.M. 2007. Advances in PCV2 research-results oh the European project № 513928: control of porcine circovirus diseases (PCVDS): Towards of improvides food quality and safety. Anais $13^{\circ}$ Congresso Brasileiro de Veterinários Especialistas em Suínos (Abraves), Florianópolis, p.239-245.

Allan G.M., McNeilly F., Kennedy S., Daft B., Clark E.D., Ellis J.A., Haines D.M., Meehan B.M. \& Adair B.M. 1998. Isolation of porcine circoviruslike viruses from pigs with a wasting disease in the United States of America and Europe. J. Vet. Diagn. Invest. 10:3-10.

Allan G.M., Kennedy S., McNeilly F., Foster J.C., Ellis J.A., Krakowka S.J., Meehan B.M. \& Adair B.M. 1999. Experimental reproduction of severe wasting disease by co-infection of pigs with porcine circovirus and porcine parvovirus. J. Comp. Pathol. 121:1-11.

Babiuk L.A., Pontarollo R., Babiuk S., Loehr B. \& van Drunen Little-van den Hurk S. 2003. Induction of immune responses by DNA vaccines in large animals. Vaccine 21:649-658.

Benvenisti L., Rogel A., Kuznetzova L., Bujanover S., Becker Y. \& Stram Y. 2001. Gene gun-mediate DNA vaccination against foot-and-mouth disease virus. Vaccine 19:3885-3895.

Blanchard P., Mahé D., Cariolet R., Keranflec H.A., Baudouart M.A., Cordioli P., Albina E. \& Jestin A. 2003. Protection of swine against 
postweaning multisystemic wasting syndrome (PMWS) by porcine circovirus type 2 (PCV2) protein. Vaccine 21:4565-4575.

Castro A.M.M.G., Cortez A., Heinemann M.B., Brandão P. \& Richtzenhain L.J. 2007. Circovirus suíno tipo 2 (PCV-2). Arqs Inst. Biológico, São Paulo, 74:281-291.

Cho H.S., Kim T.J., Lee J.I. \& Park N.Y. 2006. Serodiagnostic comparison of enzyme-linked immunosorbent assay and surface plasmon resonance for the detection of antibody to Porcine circovirus type 2. Can. J. Vet. Res. 70:263-268.

Ellis J., Hassard L., Clark E., Harding J., Allan G.M., Wilson P., Strokappe J., Martin K., McNeilly F., Meehan B., Todd D. \& Haines D. 1998. Isolation of circovirus from lesion of pigs with post-weaning multisystemic wasting syndrome. Can. Vet. J. 39:44-51.

Fenaux M., Opriessnig T., Halbur P.G., Elvinger F. \& Meng X.J. 2004. A chimeric porcine circovirus (PCV) with the immunogenic capsid gene of the pathogenic PCV type 2 (PCV-2) cloned into the genomic backbone of the nonpathogenic PCV-1 induces protective immunity against PCV2 infection in pigs. J. Virol. 78:6297-6303.

Fischer L., Barzu S., Andreoni C., Buisson N., Brun A. \& Audonnet J.C. 2003. DNA vaccination of neonate piglets in the face of maternal immunity induces humoral memory and protection against a virulent pseudorabies virus challenge. Vaccine 21:1732-1741.

Gerdts V., Jons A., Makoschey B., Visser N. \& Mettenleiter T.C. 1997. Protection of pigs against Aujeszky's disease by DNA vaccination. J. Gen. Virol. 78:2139-2146.

Hamel A.L., Lin L.L. \& Nayar G.P. 1998. Nucleotide sequence of porcine circovirus associated with postweaning multisystemic wasting syndrome in pigs. J. Virol. 72:5262-5267.

Harding J.C. \& Clark E.G. 1997. Recognizing and diagnosing postweaning multisystemic wasting syndrome (PMWS). Swine Health Prod. 5:201-203.

Hassett D.E., Zhang J. \& Whitton J.L. 1997. Neonatal DNA immunization with a plasmid encoding an internal viral protein is effective in the presence of maternal antibodies and protects against subsequent viral challenge. J. Virol. 71:7881-7888.

Hasslung F.C., Berg M., Allan G.M., Meehan B.M., McNeilly F. \& Fossum C. 2003. Identification of a sequence from the genome of porcine circovirus type 2 with an inhibitory effect on IFN-alpha production by porcine PBMCs. J. Gen. Virol. 84:2937-2945.

Kamstrup S., Barfoed A.M., Frimann T.H., Ladekjær-Mikkelsen A. \& Bøtner A. 2004. Immunization against PCV2 structural protein by DNA vaccination of mice. Vaccine 22:1358-1361.

Kim J., Chung H.K., Jung T., Cho W.S., Choi C. \& Chae C. 2002. Postweaning multisystemic wasting syndrome of pigs in Korea: prevalence, microscopic lesions and coexisting microorganisms. J. Vet. Med. Sci. 64:57-62.

Kolb J.R. 2007. Ingelvac® Circoflex ${ }^{\mathrm{TM}}$ Vaccine against pcv2 virus. 13ํㅜㅇ Congresso Brasileiro de Veterinários Especialistas em Suínos (Abraves), Florianópolis, p.239-245.

Krieg A.M. 2002. CPG motifs in bacterial DNA and their immune effects. Annu. Rev. Immunol. 20:709-760.

Lambert P.H., Margaret L. \& Siegrist C.A. 2005. Can successful vaccines teach us how to induce efficient protective immune responses? Nat. Med. 11:S54-S62.

Lecann P., Albina E., Madec F., Cariolet R. \& Jestin A. 1997. Piglet wasting disease. Vet. Rec. 141:660.

Lekcharoensuk P., Morozov I., Paul S.P., Thangthumniyom N., Wajjawalku W. \& Meng Z.J. 2004. Epitope mapping of the major capsid protein of type 2 porcine circovírus (PCV2) by using chimeric PCV1 and PCV2. J. Virol. 78:8135-8145.

Liu J., Chen I. \& Kwang J. 2005. Characterization of a previously unidentified viral protein in porcine circovirus Type 2-Infected cells and Its role in virus-induced apoptosis. J. Virol. 79:8262-8274.

Lukert P., De Boer G.F., Dale J.L., Keese P., McNulty M.S., Randles J.W. \& Tischer I. 1995. Family Circoviridae, p.166-168. In: Murphy F. A., Fauquet C.M., Bishop D.H.L., Ghabrial S.A., Jarvis A.W., Martelli G.P., Mayo M.A. \& Summers M.D. (Ed.), Virus Taxonomy. Classification and Nomenclature of Viruses. 6th Rep. Int. Commitee on Taxonomy of Viruses, New York.

Mankertz A., Mankertz J., Wolff H. \& Buhk K. 1998. Identification of protein essential for replication of porcine circovirus. J. Gen. Virol. 79:381-384

McNeilly F., Allan G.M., Foster J.C., Adair B.M. \& McNulty M.S. 1996. Effect of porcine circovirus infection on porcine alveolar macrophage function. Vet. Immunol. Immunopathol. 49:295-306.

Nawagitgul P., Morozov I., Bolin S.R., Harms P.A., Sorden S.D. \& Paul P.S. 2000. Open reading frame 2 of porcine circovirus type 2 encodes a major capside protein. J. Gen. Virol. 81:2281-2287.

Nayar G.P.S., Hamel A. \& Lin L. 1997. Detection and characterization of porcine circovirus associated with postweaning multisystemic wasting syndrome in pigs. Can. Vet. J. 38:385-386.

Park J.S., Kim J., Ha Y., Jung K., Choi C., Lim J.K., Kim S.H. \& Chae C. 2005. Birth abnormalities in pregnant sows infected intranasally with porcine circovirus 2. J. Comp. Pathol. 132:139-144.

Pogranichnyy R.M., Yoon K.J., Harms P.A., Swenson S.L., Zimmerman J.J. \& Sorden S.D. 2000. Characterization of immune response of young pigs to porcine circovirus type 2 infection. Viral Immunol. 13:143153.

Rodriguez-Arrioja G.M., Segalés J., Calsamiglia M., Resendes A.R., Balasch M., Plana-Duran J., Casal J. \& Domingo M. 2002. Dynamics of porcine circovirus type 2 infection in a herd of pigs with postweaning multisystemic wasting syndrome. Am. J. Vet. Res. 63:354-357.

Sambrook J., Fristsh E.F. \& Maniats T. 1989. Molecular Cloning: A laboratory manual. $2^{\text {nd }}$ ed. Cold Spring Harbor Laboratory Press., Cold Spring Harbor.

Sharma A.K. \& Khuller G.K. 2001. DNA vaccines: Future strategies and relevance to intracellular pathogens. Immunol. Cell Biol. 79:537-546.

Thibault S., Drolet R., Germain M.C., D-Allaire S., Larochelle R. \& Magar R. 1998. Cutaneous and systemic necrotizing vasculitis in swine. Vet. Pathol. 35:108-116.

Tischer I., Gelderblom H., Vettermenn W. \& Koch M.A. 1982. A very small porcine virus with circular single-stranded DNA. Nature 295:6466.

Ulmer J.B., Sadoff J.C. \& Liu M.A. 1996. DNA vaccines. Current Opinion Immunol. 8:531-536.

Van Oirschot J.T. 2001. Present and future of veterinary viral vaccinology: A review. Vet. Quart. 23:100-108.

West K.H., Bystrom J.M., Wojnarowicz C., Shants N., Jacobsen M., Allan G.M., Haines D.M., Clarck E.G., Krakowka S.J., McNeilly F., Konoby C.A., Martin K. \& Ellis J.A. 1999. Myocarditis and abortion associated with intrauterine infection of sows with porcine circovirus 2. J. Diagn. Invest. 11:530-532.

Zhou J.Y., Shang S.B., Gong H., Chen Q.X., Wu J.X., Shen H.G., Chen T.F. \& Guo J.Q. 2005. In vitro expression, monoclonal antibody and bioactivity for capsid protein of porcine circovirus type II withoutnuclear localization signal. J. Biotechonol. 118:201-211. 